\title{
Aplikasi Sistem Pakar Diagnosa Penyakit Pada Anak Bawah Lima Tahun Menggunakan Metode Forward Chaining
}

\author{
Bagus Fery Yanto ${ }^{1)}$, Indah Werdiningsih ${ }^{2)}$, Endah Purwanti ${ }^{3)}$ \\ ${ }^{122) 3)}$ Program Studi S1 Sistem Informasi, Fakultas Sains dan Teknologi, Universitas Airlangga \\ Kampus C Mulyorejo, Surabaya \\ ${ }^{1)}$ bagus.fery.yanto@gmail.com \\ 2)indah_werdiningsih@yahoo.co.id \\ ${ }^{3)}$ endahpurwanti@fst.unair.ac.id
}

\begin{abstract}
Abstrak- Anak-anak pada usia 2 bulan sampai 5 tahun (Balita) lebih rentan terkena penyakit. Lingkungan sangat mempengaruhi kesehatan Balita. Penelitian ini bertujuan untuk membuat sebuah aplikasi sistem pakar diagnosa penyakit pada Balita berbasis mobile. Penelitian ini terdiri dari tiga tahap. Tahap pertama adalah pengumpulan data dan informasi dari Manajemen Terpadu Balita Sakit (MTBS) dan wawancara dengan Bidan. Dari pengumpulan data dan informasi tersebut ditemukan fakta penyakit, keluhan, gejala dan saran penanganan. Tahap kedua adalah pembuatan rule dengan 18 penyakit. Tahap ketiga adalah implementasi aplikasi sistem pakar berbasis mobile dengan fitur diagnosa penyakit, riwayat diagnosa dan kumpulan penyakit. Aplikasi sistem pakar yang dibuat dapat mendiagnosa penyakit dan memberikan saran penanganan. Hasil evaluasi dari 50 data uji coba menghasilkan tingkat akurasi sebesar 82\%, dimana 41 hasil diagnosa yang benar dan 9 diagnosa yang salah.
\end{abstract}

Kata Kunci- Sistem Pakar, Forward Chaining, Diagnosa Penyakit, Manajemen Terpadu Balita Sakit, Knowladge Base

Abstract - Children at the age of 2 months to 5 years (toddlers) are more susceptible to disease contagious. Environmental condition significantly influences the children health. This research aimed to create a mobilebased expert system application to diagnose disease in toddlers. This research consist of three stages. The first stage were data and information collection from Manajemen Terpadu Balita Sakit (MTBS) and interview with medical staffs. From the first stage, we can discover the disease facts, signs, symptoms and treatment advices. The second stage was the construction of rules for 18 diseases. The third stage was the implementation of mobile-based expert system application with features of disease diagnosis, diagnosis history and collection of disease diagnosis. Expert system application made able to diagnose the disease and provide treatment advice. The results of evaluation using 50 testing data provides the level of accuracy of $82 \%$, where 41 diagnosis result were true and 9 diagnosis were false.

Keywords - Expert System, Forward Chaining, Disease Diagnosis, Manajemen Terpadu Balita Sakit, Knowledge Base

Article history:

Received 16 February 2017; Received in revised form 30 March 2017 \& 11 April 2017; Accepted 19 April 2017; Available online 28 April 2017

\section{PENDAHULUAN}

Anak-anak, terutama Balita pada usia 2 bulan sampai 5 tahun lebih rentan terhadap penyakit. Pada usia tersebut, Balita mudah terkena penyakit yang dari lingkungan tidak sehat. Berdasarkan riset yang dilakukan pemerintah Indonesia penyakit atau masalah kesehatan yang menyerang Balita masih berkisar pada yaitu gangguan perinatal, penyakit-penyakit infeksi, dan masalah kekurangan gizi (Badan Penelitian dan Pengembangan Kesehatan, 2007) Kebanyakan penyakit tersebut seharusnya bisa dicegah dan ditangani dengan mudah apabila tenaga medis bisa mendiagnosa penyakit dengan cepat dan tepat. Dengan penanganan yang cepat dan tepat akan membantu dalam menurunkan angka kematian Balita di Indonesia. Oleh karena itu, maka dibutuhkan suatu sistem yang memiliki kemampuan untuk dapat mendiagnosa gejala penyakit pada Balita seperti halnya seorang ahli atau pakar.

Bidan merupakan tenaga medis yang disiapkan dalam penanganan kesehatan ibu dan anak. Pengalaman dan pengetahuan yang dimiliki bidan dalam menangani Balita sakit dapat digunakan sebagai pendukung dalam pembuatan aplikasi sebagai seorang pakar.

Manajemen Terpadu Balita Sakit (MTBS) adalah suatu pendekatan yang terpadu dalam tatalaksana Balita sakit (Wijaya, 2009) MTBS merupakan suatu bentuk strategi upaya pelayanan kesehatan yang ditujukan untuk menurunkan angka kematian, kesakitan dan kecacatan bayi dan Balita di negara - negara berkembang.

Kecerdasan Buatan sudah sering digunakan dalam aplikasi medis sebagai solusi pelengkap untuk menemukan solusi dalam permasalahan 
medis (Obot, 2010). Munculnya teknologi kecerdasan buatan dalam bidang kesehatan memacu pengembangan aplikasi sistem pakar untuk layanan kesehatan, salah satunya adalah proses diagnosa penyakit. Dengan menggabungkan pendekatan MTBS, pengetahuan Bidan dan kecerdasan buatan akan dibuat sistem pakar untuk mendiagnosa penyakit pada Balita.

Sistem pakar merupakan bidang studi pada Kecerdasan Buatan yang sudah ada dalam beberapa dekade (William P. Wagner, 2017). Sistem pakar dapat digunakan untuk mendiagosa penyakit balita, misalnya sistem pakar untuk mendeteksi penyakit paru-paru kronis yang diderita oleh bayi secara dini (Marcin Ochab, 2016).

Metode forward chaining merupakan salah satu dari metode dalam sistem pakar (Cut Fiarnia, 2015). Pada penelitian sebelumnya sistem pakar yang menggunakan metode forward chaining memberikan hasil diagnosa sesuai dengan fakta fakta yang diinputkan user. Sistem pakar dengan metode forward chaining dalam bidang diagnosa kesehatan telah digunakan dalam beberapa penelitian diantaranya Pembuatan Aplikasi Diagnosa Penyakit Jantung Berdasarkan Faktor Resiko dan Gejala dengan Metode Forward Chaining dan Certainly Factor (Dewi, 2009). Implementasi Metode Forward Chaining untuk Pendeteksian Dini Penyakit Diabetes Melitus (Harahap, Suyanto, \& Ariyanto, 2009), dan Aplikasi Sistem Pakar Diagnosa Penyakit Menular pada Balita dengan Metode Forward Chaining (Yohan Kurnia Putra Tjumoko, 2012).

Pada penelitian ini akan dibangun sistem pakar berbasis rule based sistem menggunakan metode forward chaining. Penggunaan metode forward chaining di penelitian ini karena program aplikasi sistem pakar yang dibangun membutuhkan suatu masukan data dari user dan pendekatan yang terdapat dalam MTBS berupa inferensi, dimana basis pengetahuan yang terdapat dalam MTBS diekstrak kedalam sistem pakar. Dengan dibuat dan dirancang sistem pakar ini diharapkan dapat mendiagnosa penyakit pada Balita dengan cepat dan tepat.

\section{METODE PENELITIAN}

Metode yang digunakan dalam penelitian terdiri dari pengumpulan data dan informasi, pengolahan data dan informasi, perancangan, implementasi, ujicoba dan evaluasi.

\section{A. Pengumpulan Data dan Informasi}

Pengumpulan data dan informasi dilakukan dengan cara studi pustaka dan wawancara.

Studi pustaka: Studi pustaka dilakukan dengan cara memahami dan mempelajari lebih dalam pendekatan MTBS dan penyelesaian masalah.
Wawancara: Wawancara dilakukan dengan Bidan untuk mengetahui cara dalam menuntukan gejala yang diderita Balita.

\section{B. Pengolahan Data dan Informasi}

Pengolahan data dilakukan melalui beberapa tahapan yaitu studi pustaka, wawancara, analisis data dalam basis pengetahuna.

Studi pustaka: Hasil dari studi pustaka pendekatan MTBS dikumpulkan data mengenai penyakit, keluhan, gejala dan saran penanganan.

Wawancara:Hasil wawancara digunakan sebagai acuan dalam proses mendiagnosa dan tambahan keterangan dalam basis pengetahuan.

Analisis data dalam basis pengetahuan:Data yang sudah didapat dimasukkan dalam basis pengetahuan kemudian dipilah mana yang dijadikan sebagai inputan sistem dan output sistem.

\section{Pengolahan data dan informasi}

Dari data yang sudah didapatkan dari analisa data kemudian dikunsultasikan dengan Bidan. Setelah itu data yang sudah diperoleh dijadikan aturan menggunakan metode forward chaining. Dari aturan-aturan yang sudah dibuat dimasukkan ke dalam basis pengetahuan (knowledge base).

\section{Perancangan Sistem}

Pada penelitian ini alur aplikasi sistem pakar yang akan dibuat dapat dilihat pada Gambar 1

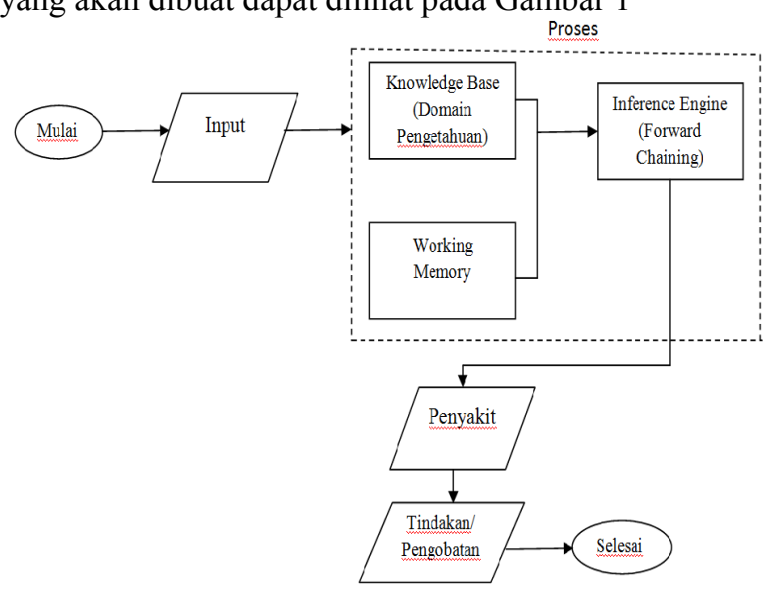

Gambar 1. Gambaran Umum sistem

Berikut penjelasan gambaran umum sistem : 1. Input, merupakan pertanyaan-pertanyaan yang muncul dalam aplikasi sistem pakar.

2. Knowledge base (domain pengetahuan), pengetahuan mengenai klasifikasi penyakit berdasarkan buku bagan MTBS yang dijadikan sebagai rule-based.

3. Working memory, fakta-fakta yang diinputkan oleh pengguna kedalam aplikasi sistem pakar.

4. Inference Engine, proses pencocokan faktafakta yang ada pada working memory dengan 
domain pengetahuan, untuk menrik kesimpulan dari masalah yang dihadapi.

5. Klasifikasi penyakit, hasil kesimpulan dari proses diagnosa sistem pakar

6. Tindakan/pengobatan, tata cara penanganan yang bisa dilakukan oleh pengguna.

Diagram yang digunakan dalam perancangan aplikasi yang dibuat adalah use case diagram dan acyivity diagram

\section{E. Implementasi sistem}

Implementasi pada sistem dilakukan untuk membangun aplikasi diagnosa penyakit pada anak Balita. Aplikasi yang dibangun berbasis mobile yang menggunakan sistem operasi Android dengan Java sebagai bahasa pemrogramannya.Tools yang digunakan dalam implementasi sistem adalah Android Studio 1.0.

\section{F. Pengujian sistem}

Pengujian dilakukan dengan menggunakan satu data uji coba. Hasil uji coba data sampling digunakan untuk melihat respon sistem ketika menerima inputan.

\section{G. Evaluasi sistem}

Berdasarkan pengujian sistem, evaluasi sistem dilakukan dengan mencocokkan 50 hasil diagnosa bidan dengan hasil diagnosa sistem. Evaluasi ini dilakukan untuk mengukur akurasi aplikasi yang dibangun dalam mendiagnosa penyakit.

\section{HASIL DAN PEMBAHASAN}

\section{A. Pengumpulan Data dan Informasi}

Pengumpulan data dan informasi dilakukan beberapa tahap yaitu studi wawancara, dan studi pustaka. Berikut adalah hasil dari tahapan pengumpulan data dan informasi.

1) Hasil Wawancara : berdasarkan hasil wawancara diketahui cara mengetahui gejala yang dialami Balita. Untuk menentukan keluhan dan gejala yang dialami oleh Balita dapat dilakukan dengan cara tanya jawab dengan orang tua tentang keluhan, pemeriksaan fisik secara langsung dan pemeriksaaan penunjang

2) Studi Pustaka : Studi pustaka untuk peneyelesaian masalah diambil dari buku, jurnal dan skripsi mengenai metode forward chaining. Hasil studi pustaka yang dilakukan diperoleh langkah-langkah metode forward cahining. Dari pendekatan MTBS didapatkan data dan iformasi mengenai fakta gejala, penyakit dan keluhan yang dialami oleh Balita yang ditampilkan pada Tabel 1, Tabel 2 dan Tabel 3

\section{B. Pembuatan Rule Based}

Dari fakta yang sudah didapat kemudian dirubah menjadi aturan (rule) berdasarkan 18 penyakit. Berdasarkan penyakit tersebut dihasilkan 108 aturan, Aturan yang dibuat berdasarkan dari domain pengetahuan pakar. Tabel 4 menunjukkan contoh beberapa aturan yang dibuat berdasarkan penyakit.

TABEL 1.TABEL GEJALA

\begin{tabular}{|c|c|}
\hline Kode & Gejala \\
\hline G1 & Anak tidak bisa minum atau menyusu \\
\hline G2 & $\begin{array}{l}\text { Anak memuntahkan makanan yang } \\
\text { dimakan }\end{array}$ \\
\hline G3 & Anak menderita kejang \\
\hline G4 & Anak tampak letargis atau tidak sadar \\
\hline G5 & Napas Normal \\
\hline G6 & Napas cepat \\
\hline G7 & Tarikan dinding dada ke dalam \\
\hline G8 & Stridor \\
\hline G9 & Berak cair atau lembek \\
\hline G10 & Mata cekung \\
\hline G11 & Cubitan kulit perut kembali lambat \\
\hline G12 & Gelisah, rewel/mudah marah \\
\hline G13 & Haus, minum dengan lahap \\
\hline G14 & Cubitan kulit perut sangat lambat \\
\hline G15 & Anak tampak letargis atau tidak sadar \\
\hline G16 & Tidak bisa minum atau malas minum \\
\hline G17 & Diare 14 hari atau lebih \\
\hline G18 & Ada darah dalam tinja \\
\hline G19 & Suhu badan melebihi $37.5^{\circ} \mathrm{C}$ \\
\hline G20 & $\begin{array}{l}\text { Kaku kuduk (anak tidak bisa menunduk } \\
\text { hingga dagu mencapai dada) }\end{array}$ \\
\hline G21 & Ruam kemerahan di kulit \\
\hline G22 & batuk pilek atau mata merah \\
\hline G23 & Luka di mulut yang dalam atau luas \\
\hline $\mathrm{G} 24$ & Kekeruhan pada kornea mata \\
\hline $\mathrm{G} 25$ & Luka di mulut \\
\hline G26 & Mata bernanah \\
\hline G27 & Demam $2-7$ hari \\
\hline $\mathrm{G} 28$ & $\begin{array}{l}\text { Demam mendadak tinggi dan terus } \\
\text { menerus }\end{array}$ \\
\hline G29 & Nyeri di ulu hati \\
\hline G30 & bintik bintik merah \\
\hline G31 & Muntah bercampur darah / seperti kopi \\
\hline G32 & Tinja berwarna hitam \\
\hline G33 & Perdarahan dihidung dan gusi \\
\hline G34 & Syok dan gelisah \\
\hline G35 & Infeksi \\
\hline G36 & Pilek \\
\hline
\end{tabular}

TABEL 2.TABEL PENYAKIT

\begin{tabular}{|c|l|c|l|}
\hline Kode & \multicolumn{1}{|c|}{$\begin{array}{c}\text { Klasifikasi } \\
\text { Penyakit }\end{array}$} & Kode & \multicolumn{1}{|c|}{$\begin{array}{c}\text { Klasifikasi } \\
\text { Penyakit }\end{array}$} \\
\hline P1 & $\begin{array}{l}\text { Tanda Bahaya } \\
\text { Umum }\end{array}$ & P10 & Disentri \\
\hline P2 & Batuk & P11 & Demam \\
\hline P3 & Pneumonia & P12 & $\begin{array}{l}\text { Demam dengan } \\
\text { Umum Bahaya }\end{array}$ \\
\hline P4 & $\begin{array}{l}\text { Pneumonia } \\
\text { Berat }\end{array}$ & P13 & Campak \\
\hline P5 & Diare & P14 & $\begin{array}{l}\text { Campak dengan } \\
\text { komplikasi berat }\end{array}$ \\
\hline P6 & $\begin{array}{l}\text { Diare Dehidrasi } \\
\text { Ringan }\end{array}$ & P15 & $\begin{array}{l}\text { Campak dengan } \\
\text { komplikasi }\end{array}$ \\
\hline P7 & $\begin{array}{l}\text { Diare Dehidrasi } \\
\text { Berat }\end{array}$ & P16 & $\begin{array}{l}\text { Demam } \\
\text { Mungkin DBD }\end{array}$ \\
\hline P8 & Diare Persisten & P17 & DBD \\
\hline P9 & $\begin{array}{l}\text { Diare Persisten } \\
\text { Berat }\end{array}$ & P18 & $\begin{array}{l}\text { Demam bukan } \\
\text { DBD }\end{array}$ \\
\hline
\end{tabular}


TABEL 3.TABEL KELUHAN

\begin{tabular}{|c|c|}
\hline Kode & Keluhan \\
\hline K1 & Batuk \\
\hline K2 & Diare \\
\hline K3 & Demam \\
\hline & \\
\hline
\end{tabular}

\section{Penerapan Metode Forward Chaining}

Dalam sistem pakar yang dibangun penelusuran menggunakan adalah forward chaining, apabila bagian premis (jika) terpenuhi maka bagian konklusi (maka) juga akan bernilai benar. Berikut langkah - langkah penelusuran dengan forward chaining:

Langkah 1: mengajukan pertanyaan kepada user

Langkah 2: menampung inputan dari user sebagai fakta yang diketahui pada short term memory yang disimpan pada tiap variabel pertanyaan yang diajukan

Langkah 3: memeriksa rule berdasarkan fakta pada short term memory menggunakan metode forward chaining.

Langkah 4: jika rule ditemukan maka konklusi rule ditampung pada short term memory, apabila ada fakta baru maka langkah satu sampai dengan langkah empat diulang. Jika rule tidak ditemukan maka berikan default output.

Langkah 5: memberikan solusi.

TABEL 4. ATURAN UNTUK DIAGNOSA PENYAKIT

\begin{tabular}{|c|c|c|}
\hline Rule & IF & THEN \\
\hline 1 & G1 OR G2 OR G3 OR G4 & P1 \\
\hline 2 & K1 AND G5 & $\mathrm{P} 2$ \\
\hline 3 & K1 AND G6 & P3 \\
\hline 4 & K1 AND P1 OR G7 OR G8 & P4 \\
\hline 5 & K2 AND G9 & P5 \\
\hline 6 & $\begin{array}{l}\text { P5 AND G10 AND G11 OR G12 } \\
\text { OR G13 }\end{array}$ & P6 \\
\hline 7 & $\begin{array}{l}\text { P5 AND G10 AND G14 OR G15 } \\
\text { OR G16 }\end{array}$ & P7 \\
\hline 8 & P5 AND G17 & P8 \\
\hline 9 & P8 AND P6 OR P7 & P9 \\
\hline 10 & P5 AND G18 & $\mathrm{P} 10$ \\
\hline 11 & K3 AND G19 & P11 \\
\hline 12 & P1 AND P11 OR G20 & P12 \\
\hline 13 & P11 AND G21 AND G22 OR G25 & P13 \\
\hline 14 & P13 AND P1 AND G23 OR G24 & P14 \\
\hline 15 & P13 AND G25 OR G26 & P15 \\
\hline 16 & $\begin{array}{l}\text { P11 AND G27 AND G28 AND } \\
\text { G29 OR G30 }\end{array}$ & P16 \\
\hline 17 & $\begin{array}{l}\text { P11 AND G27 AND G28 AND } \\
\text { G31 OR G32 OR G33 OR G34 }\end{array}$ & P17 \\
\hline 18 & P11 AND G35 OR G36 & P18 \\
\hline
\end{tabular}

\section{Perancangan Sistem}

Untuk mempresentasikan tiap fitur yang terdapat dalam aplikasi digunakan use case diagram yang ditampilkan pada Gambar 2. Adapun proses yang disusun berdasarkan fitur yang dibuat sebagai berikut:

1) Melakukan diagnosa :proses ini menggambarkan proses diagnosa sistem pakar. Dalam proses ini pengguna terlebih dahulu menginputkan nama, umur dan alamat Balita yang akan didiagnosa. Setelah itu aplikasi akan memunculkan pertanyaan-pertanyaan gejala yang harus dijawab oleh user. Dari jawaban yang diinputkan oleh user, aplikasi akan menampilkan hasil diagnosa beserta tindakan yang akan diberikan dan dapat menyimpan hasil diagnosa.

2) Melihat kumpulan penyakit: proses ini dapat digunakan oleh user untuk menambah wawasan mengenai penyakit-penyakit yang dapat dialami oleh Balita. Pada proses ini akan ditampilkan beberapa penyakit yang dapat dialami oleh Balita. Apabila pengguna memilih salah satu penyakit akan muncul detail penyakit, gejala dan penanganannya.

3) Melihat riwayat pasien: pada proses ini digunakan untuk melihat data-data hasil diagnosa Balita yang sudah diproses. Fitur ini semua data pasien yang sudah diproses oleh aplikasi akan ditampilkan. User dapat melihat detail diagnosa yang dilakukan oleh aplikasi. Selain itu untuk memudahkan user untuk melakukan pencarian berdasarkan nama.

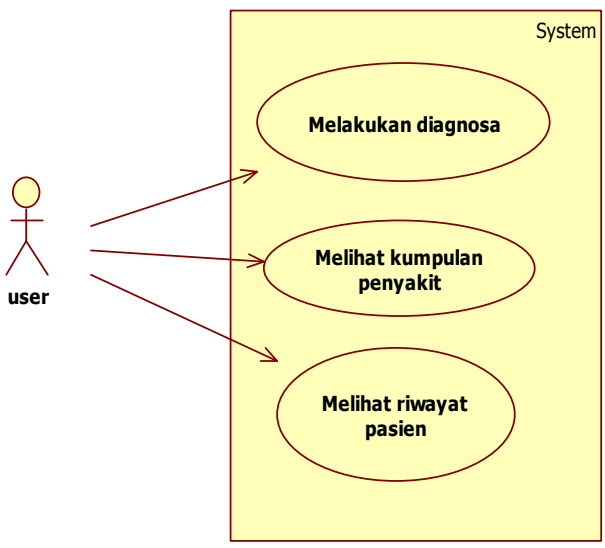

Gambar 2. Use Case Sistem yang Dibangun

\section{E. Implementasi Sistem}

Implementasi penelitian ini dibangun menggunakan bahasa pemrograman Java berbasis Android dan database SQLite. Database SQLite digunakan untuk menyimpan hasil output aplikasi. Berikut implementasi yang dilakukan:

1) Diagnosa Penyakit Balita :fitur ini digunakan untuk mendiagnosa penyakit pada Balita. Sebelum melakukan proses diagnosa dilakukan pengguna harus memasukkan data identitas Balita pada 
antarmuka home. Antarmuka home terdapat dua fitur yaitu, fitur pertanyaan dan fitur hasil diagnosa. Setelah memasukkan data identitas maka akan memulai mendiagnosa dengan mengisi pertanyaan pada antarmuka pertanyaan. Kemudian akan menghasilkan hasil diagnosa pada antarmuka hasil diagnosa. Halaman antarmuka pertanyaan dan hasil diagnosa dapat dilihat pada Gambar 3 dan Gambar 4.

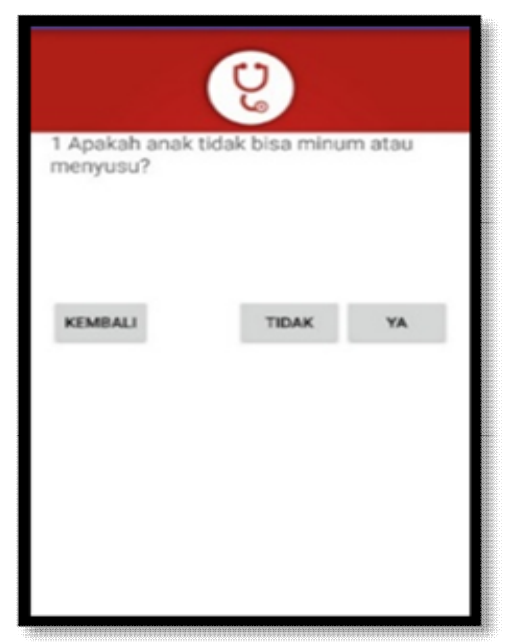

Gambar 3. Halaman antarmuka pertanyaan

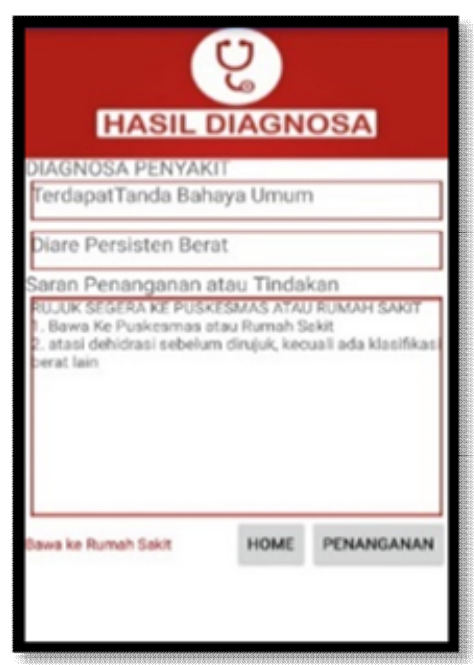

Gambar 4. Halaman antarmuka Hasil Diagnosa

2) Riwayat Diagnosa : Fitur riwayat diagnosa digunakan untuk melihat riwayat diagnosa pasien dan pencarian berdasarkan nama Balita. Untuk membuka fitur ini pengguna menekan icon "Riwayat". Antarmuka riwayat pasien dan pencarian dapat dilihat pada Gambar 5 dan 6.

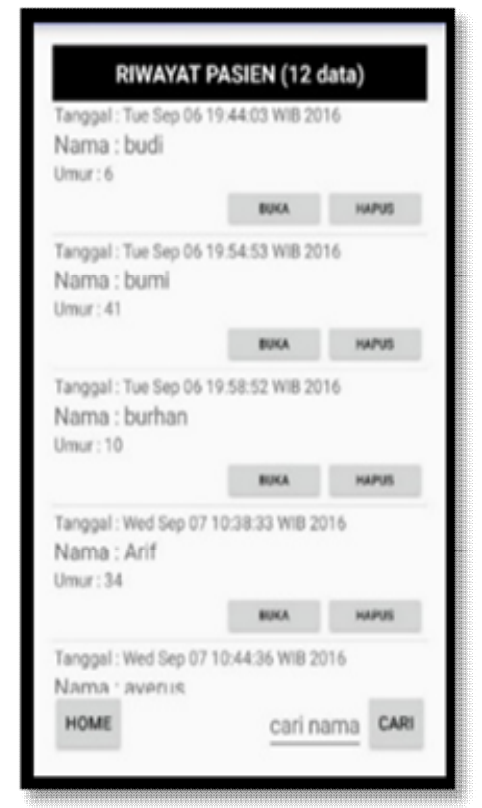

Gambar 5. Halaman antarmuka Riwayat Pasien

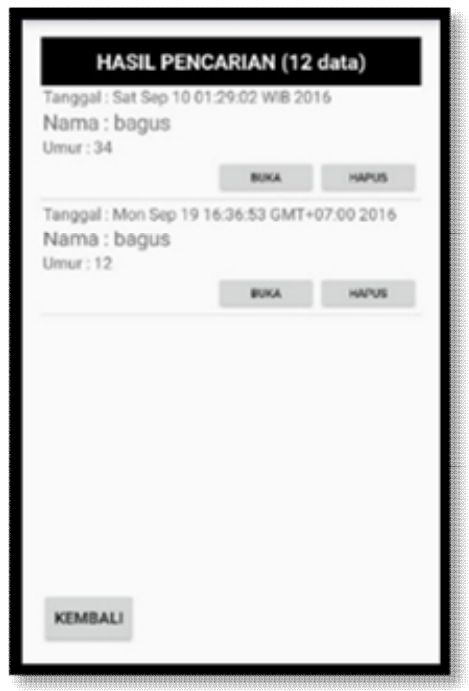

Gambar 6. Halaman antarmuka Hasil Pencarian

3) Penyakit : Fitur ini pengguna dapat mempelajari penyakit pada balita. Fitur ini dapat dibuka dengan menekan icon berlambang penyakit. Ketika dibuka akan ditampilkan beberapa penyakit, yaitu : Pneomania, Diare, Demam, Campak, dan Demam Berdarah Dengue. Dengan mengklik nama penyakit, akan muncul detail penyakit, gejala dan tindakan. Halaman detail penyakit dapat dilihat pada Gambar 7 


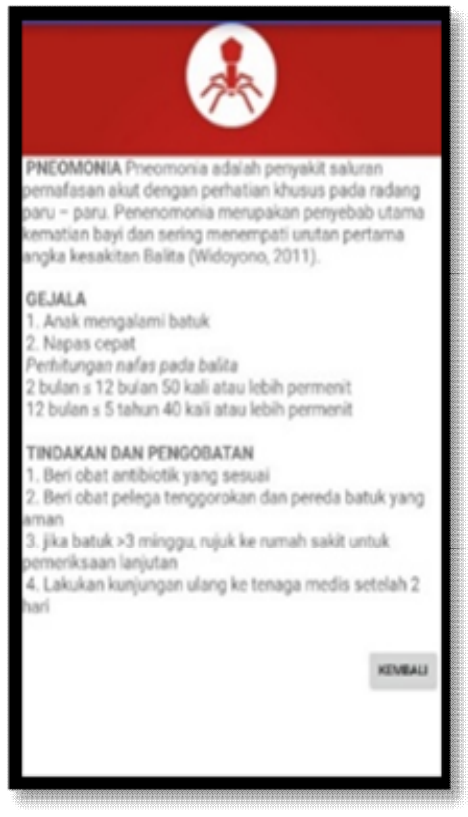

Gambar 7. Halaman detail penyakit

Tabel 5.TABel Pengujian Data

\begin{tabular}{|c|c|c|c|c|}
\hline Data & $\begin{array}{c}\text { Gejala yang } \\
\text { Dialami }\end{array}$ & $\begin{array}{c}\text { Diagnosa } \\
\text { Bidan }\end{array}$ & $\begin{array}{l}\text { Output } \\
\text { Sistem }\end{array}$ & Keterangan \\
\hline Data 1 & $\begin{array}{l}\text { Suhu badan } 38,5 \\
\text { C,anak batuk } \\
\text { selama } 42 \text { hari, } \\
\text { nafas dalam satu } \\
\text { menit } 43 \text { kali, } \\
\text { Agak pucat, }\end{array}$ & Pneumonia & Demam & $\begin{array}{l}\text { Tidak } \\
\text { Sesuai }\end{array}$ \\
\hline Data 2 & $\begin{array}{l}\text { Suhu badan } 37,5 \\
\text { C, keluhan } \\
\text { batuk, nafas } \\
\text { cepat, nafas } \\
\text { dalam satu menit } \\
43 \text { kali, batuk } \\
\text { selama } 3 \text { hari, } \\
\text { agak pucat }\end{array}$ & Pneumonia & Pneumonia & Sesuai \\
\hline Data 3 & $\begin{array}{l}\text { Suhu badan } 38,5 \\
\text { C, keluhan } \\
\text { batuk, nafas } \\
\text { normal, nafas } \\
\text { dalam satu menit } \\
35 \text { kali, batuk } \\
\text { selama } 4 \text { hari, } \\
\text { agak pucat }\end{array}$ & Demam & Batuk & $\begin{array}{l}\text { Tidak } \\
\text { Sesuai }\end{array}$ \\
\hline Data 4 & $\begin{array}{l}\text { Suhu badan } 37,5 \\
\text { C, keluhan } \\
\text { batuk, nafas } 38 \\
\text { kali dalam satu } \\
\text { menit, batuk } \\
\text { selama } 3 \text { hari, } \\
\text { agak pucat }\end{array}$ & Batuk & Batuk & Sesuai \\
\hline Data 5 & $\begin{array}{l}\text { Suhu badan } 38 \\
\text { C,anak batuk } \\
\text { selama } 1 \text { hari, } \\
\text { nafas dalam satu } \\
\text { menit } 45 \text { kali, } \\
\text { Agak pucat, }\end{array}$ & Pneumonia & Demam & $\begin{array}{l}\text { Tidak } \\
\text { Sesuai }\end{array}$ \\
\hline . & . & . & . & . \\
\hline . & $\cdot$ & . & $\cdot$ & . \\
\hline $\begin{array}{l}\text { Data } \\
50\end{array}$ & $\begin{array}{c}\text { Suhu badan } 38 \\
\text { C, anak batuk } \\
\text { pilek selama } 3 \\
\text { hari, nafas } 41 \\
\text { kali dalam satu } \\
\text { menit } \\
\end{array}$ & Demam & Batuk & $\begin{array}{l}\text { Tidak } \\
\text { Sesuai }\end{array}$ \\
\hline \multicolumn{4}{|c|}{ Jumlah Sesuai } & 41 \\
\hline & Jumlah T & ak Sesuai & & 9 \\
\hline
\end{tabular}

\section{F. Uji Coba Sistem}

Uji coba digunakan untuk menguji seberapa baik kinerja dari aplikasi yang dibuat. Hasil ujicoba sistem untuk 50 data dapat dilihat pada Tabel 5 .

\section{G. Evaluasi Sistem}

Evaluasi sistem dilakukan dengan mengujikan 50 data uji coba untuk mengevaluasi akurasi sistem. Berdasarkan Tabel 5, maka dari 50 data yang diujikan, 41 data menunjukkan hasil yang sama dengan hasil diagnosa pakar sehingga hasil presentase akurasi sistem pakar sebesar $82 \%$.

\section{KESIMPULAN}

Berdasarkan hasil penelitian maka disimpulkan bahwa pembuatan aplikasi sistem pakar diagnosa penyakit pada Balita menggunakan metode forward chaining dapat dilakukan dengan tiga tahap. Tahap pertama adalah pengumpulan data dan informasi dari MTBS dan wawancara. Tahap kedua adalah pembuatan rule berdasarkan 18 penyakit menggunakan metode forward chaining. Tahap ketiga adalah implementasi aplikasi sistem pakar berbasis android dengan fitur diagnosa penyakit, riwayat diagnosa dan kumpulan penyakit. Hasil evaluasi menunnjukkan tingkat akurasi sistem yang telah dibuat sebesar $82 \%$ dengan menggunakan 50 data uji coba.

\section{DAFTAR PUSTAKA}

Badan Penelitian dan Pengembangan Kesehatan, D. K. (2007). Laporan Nasional Riset Kesehatan Dasar (Riskesdas). Indonesia.

Cut Fiarnia, A. S. (2015). Automated Scheduling System for Thesis and Project Presentation Using Forward Chaining Method With Dynamic Allocation Resources. Procedia Computer Science, 209-216.

Dewi, A. (2009). Pembuatan Aplikasi Diagnosa Penyakit Jantung Berdasarkan Faktor Resiko dan Gejala dengan Metode Forward Chaining dan Certainly Factor.

Harahap, E., Suyanto, \& Ariyanto, E. (2009). Implementasi Metode Forward Chaining Untuk Pendektesian Dini Penyakit Diabetis Mellitus. Bandung: Telkom University.

Marcin Ochab, W. W. (2016). Expert System Supporting an Early Prediction of The Brochopulmonary Dysplasia. Computers in Biology and Medicine, 236-244.

Obot, O. U. (2010). Experimental Comparison of Fuzzy Logic and Analytic Hierarchy Process for Medical Decision Support Systems. Computer Methods and Programs in Biomedicine, 123130.

Wijaya, A. M. (2009). Manajemen Terpadu Balita Sakit (MTBS) atau Integrated Management of Childhood Illaness (IMCI). Indonesia.

William P. Wagner. (2017). Trends in Expert System Development : A Longitudinal Content Analysis of Over Thirty Years of Expert System Case Studies. Expert System With Applications, 85-96. 
Bagus Fery Yanto, Indah Werdiningsih, Endah Purwanti Journal of Information Systems Engineering and Business Intelligence, 2017, 3 (1), 61-67

Yohan Kurnia Putra Tjumoko, A. S. (2012). Aplikasi Sistem Pakar Diagnosis Penyakit Menular Pada Balita Dengan Metode Forward Chaining. JSIKA, 1-8. 